\title{
Incidence and significance of cystic structures in the ovaries of gadoid fish
}

\author{
ROSARIO DOMÍNGUEZ-PETIT, ALEXANDRE ALONSO-FERNÁNDEZ \\ and FRAN SABORIDO-REY
}

Institute of Marine Research (CSIC), Eduardo Cabello, 6, 36208 Vigo, Spain. E-mail: rosario@iim.csic.es

\begin{abstract}
SUMMARY: Fish regulate egg production by atresia. Sometimes, oocytes are encapsulated in cystic structures that might remain in the ovary for months, altering female reproductive potential in future spawning seasons. Ovaries of Atlantic cod (Gadus morhua, L.) from the Flemish Cap and European hake (Merluccius merluccius, L.) from the Galician Shelf (NW Spain) were analysed from 1999 to 2006. The prevalence and abundance of ovarian cysts were estimated. Cyst prevalence increased with female size and/or age for both species, and decreased with high condition factor in hake. Cyst intensity does not correlate with any analysed factor. The size/age structure of spawning stock biomass and female condition could affect the prevalence of cysts in the ovaries, though it does not seem to affect cyst intensity in the ovary. Further research is needed to determine cyst resorption time and the impact that it has on egg production and consequently on stock reproductive potential.
\end{abstract}

Keywords: European hake, Atlantic cod, cyst, ovarian follicle, condition, reproductive potential.

RESUMEN: INCIDENCIA Y SIGNIFICANCIA DE LAS ESTRUCTURAS CÍSTICAS EN OVARIOS DE GÁDIDOS. - Los peces regulan la producción de huevos a través de la atresia. En ocasiones, los ovocitos son encapsulados en estructuras quísticas que podrían permanecer en el ovario durante meses, alterando el potencial reproductivo de las hembras en estaciones de puesta posteriores. Se tomaron ovarios de bacalao (Gadus morhua, L.) de Flemish Cap y de merluza europea (Merluccius merluccius, L.) de la costa gallega (NO España) entre 1999 y 2006. Se estimó la prevalencia e intensidad de quistes en estos ovarios. En ambas especies la prevalencia de hembras con quistes aumentó con la talla y/o edad y disminuyó al aumentar el factor de condición en el caso de la merluza. La intensidad de quistes no se correlacionó con ninguna de las variables estudiadas. La estructura de talla/edades del stock reproductor y la condición de las hembras podría afectar la prevalencia de hembras con quistes. Son necesarios más estudios para determinar el tiempo de reabsorción de estos quistes y las consecuencias que esto puede tener en la producción de huevos y por tanto en el potencial reproductivo de los stocks.

Palabras clave: merluza europea, bacalao atlántico, quiste, folículo ovárico, condición, potencial reproductivo.

\section{INTRODUCTION}

Teleost oocytes are composed of the nucleus and ooplasm surrounded by the oolema (or viteline envelope) and zona radiata; two these last layers are known as the chorion. The follicle is formed by the oocyte and the surrounding layers (in mature follicles, the granulosa and superficial epithelium or theca). When meiotic division begins, oogonias are surrounded by a thin simple squamous epithelium (pre-follicular cells); as the follicle matures, this epithelium becomes cuboi- dal or columnar and, in some species, it is stratified (McMillan, 2007). In Atlantic cod and European hake, the superficial epithelium of mature follicles is simple and cuboidal (personal observations).

Females may resorb mature follicles at different developmental stages via atresia. Follicular atresia is an involutive process common in the ovaries of fish and other vertebrates (Saidapur, 1978; Guraya, 1986; Hirshfield, 1991). Similar atresia processes occur in all fish species: cells from the granulosa invade the cytoplasm of the oocyte and digest the ooplasm by phagocytosis 
until the oocyte has completely disintegrated and the follicular membrane has collapsed (Guraya, 1986). The incidence of atresia is reportedly affected by maternal status (Ganias et al., 2003; Rideout et al., 2006); food availability (Solemdal, 1997; Bromley et al., 2000); parasitic infections (Clarke et al., 2006); environmental conditions such as temperature (Linares-Casenave et al., 2002; Privalikhin, 2003), $\mathrm{pH}$ or the presence of pollutants (Wootton, 1990; Domínguez-Petit and Saborido-Rey, 2005); increases in stock abundance (density-dependent effect; Privalikhin, 2003); and imbalances in population sex-ratios (Rideout et al., 2000). Atresia may occur at any time during the spawning season, and can even occur before spawning (Marshall et al., 2003; Murua et al., 2003; Rideout et al., 2000). After the end of the spawning season, residual oocytes become atretic and atresia intensity is higher at this time in species with indeterminate fecundity than in species with determinate fecundity (Murua and Saborido-Rey 2003). Overall, atresia regulates fish egg production, reducing potential fecundity and allowing females to recover part of the energy invested in oocytes (Guraya, 1986).

However, in some cases, an atypical swelling of the follicular envelope takes place instead of the normal atretic process, leading to cyst formation. The cause of this atypical occurrence is unknown despite observations of cystic follicles in several species, including Gadus morhua (Tomkiewicz et al., 2003; Witthames et al., 2010), Lepidorhombus boscii, Trisopterus luscus, Merluccius merluccius (personal observations), M. capensis, M. paradoxus (R. Osborne, pers. comm.), Scomber scombrus (P. Witthames, pers. comm.) and Macruronus novaezelandiae (P. Grimes, pers. comm.). There are few specific works on these cystic structures beyond brief mentions in the literature concerning fish reproductive ecology (Louge, 1996; Tomkiewicz et al., 2003; Witthames et al., 2010) and purely descriptive works (Domínguez-Petit and Saborido-Rey, 2005). As these cystic follicles may have significant effects on stock reproductive potential (SRP) through reduction of fecundity in the current and future spawning seasons, it is essential to determine why certain follicles develop into cysts and what factors control cyst occurrence, abundance and resorption time.

The present study focuses on two gadoid species: European hake (Merluccius merluccius) from the northeast Atlantic (NW Spanish coast) and Atlantic cod (Gadus morhua) from the northwest Atlantic (Flemish Cap). The European hake is an indeterminate batch spawner; along the northwest Spanish coast it has a protracted spawning season with a main peak in February and a secondary peak between late spring and early summer, depending on the year (Murua and Motos, 2006; Dominguez-Petit, 2007). In contrast, the Atlantic cod is a determinate batch spawner with peak spawning activity in the Flemish Cap occurring in March (Lilly and Vázquez, 2005). In general, fishes with indeterminate fecundity, such as the European hake, show a generalized prevalence of atresia and resorption of mature oocytes at the end of the spawning season. In fishes with determinate fecundity, including the Atlantic cod, atresia occurs sparsely throughout the reproductive season (Murua and Saborido-Rey, 2003); massive atresia is rare and when it does takes place, at or just prior to spawning, it is considered a signal of reproductive failure.

The present work describes the morphology of cystic structures in the European hake and Atlantic cod and analyses the incidence of follicular cyst formation across age, size and condition factor.

\section{MATERIALS AND METHODS}

In total, 2244 and 1097 females were sampled for European hake (Merluccius merluccius) from the Galician Shelf and Atlantic cod (Gadus morhua) from the Flemish Cap, respectively. Atlantic cod samples were obtained during annual summer scientific surveys from 2001 to 2006; European hake were sampled monthly in 1999, 2000, 2003 and 2004. Total length and gutted weight was determined for each specimen and condition factor was estimated according to the following equation:

$$
K=\frac{G W}{L^{3}}
$$

where GW is the gutted weight and L is the total length of each female.

Ovaries were preserved in $4 \%$ buffered formaldehyde for histological analysis. For each female, one ovary sub-sample was taken from the mid-ovary, embedded in paraffin and cut into $3 \mu \mathrm{m}$ sections, which were stained with haematoxylin and eosin. One section per ovary was examined with a light microscope to determine the presence or absence of cysts. Cyst prevalence was defined as the percentage of females with ovarian cysts, relative to the total number of sampled mature females. Of the females with cysts, some were selected covering the whole size range (see $n$-value for each analysis in the Results section) in order to estimate cyst intensity by stereological methods (Weibel, 1979). Four images (magnification $\times 5$ ) from each ovary section were analysed following the protocol described in Domínguez-Petit (2007). Cyst intensity within the individual was expressed as the percentage of ovary volume occupied by cysts, and was estimated by applying the Cavalieri Principle and point-counting method to the histological sections; the precision of the estimators was determined using the Matheron-Gundersen-Jensen estimator to calculate the Nugget effect that represents variations at a much smaller scale than any of the measured pairwise distances (Gundersen and Jensen, 1987), i.e. the effect of nonuniform distribution of particles in the sample. When only a single point was positive (upon a cyst) in the Weibel grid, assigned intensity value was $0.15 \%$. 

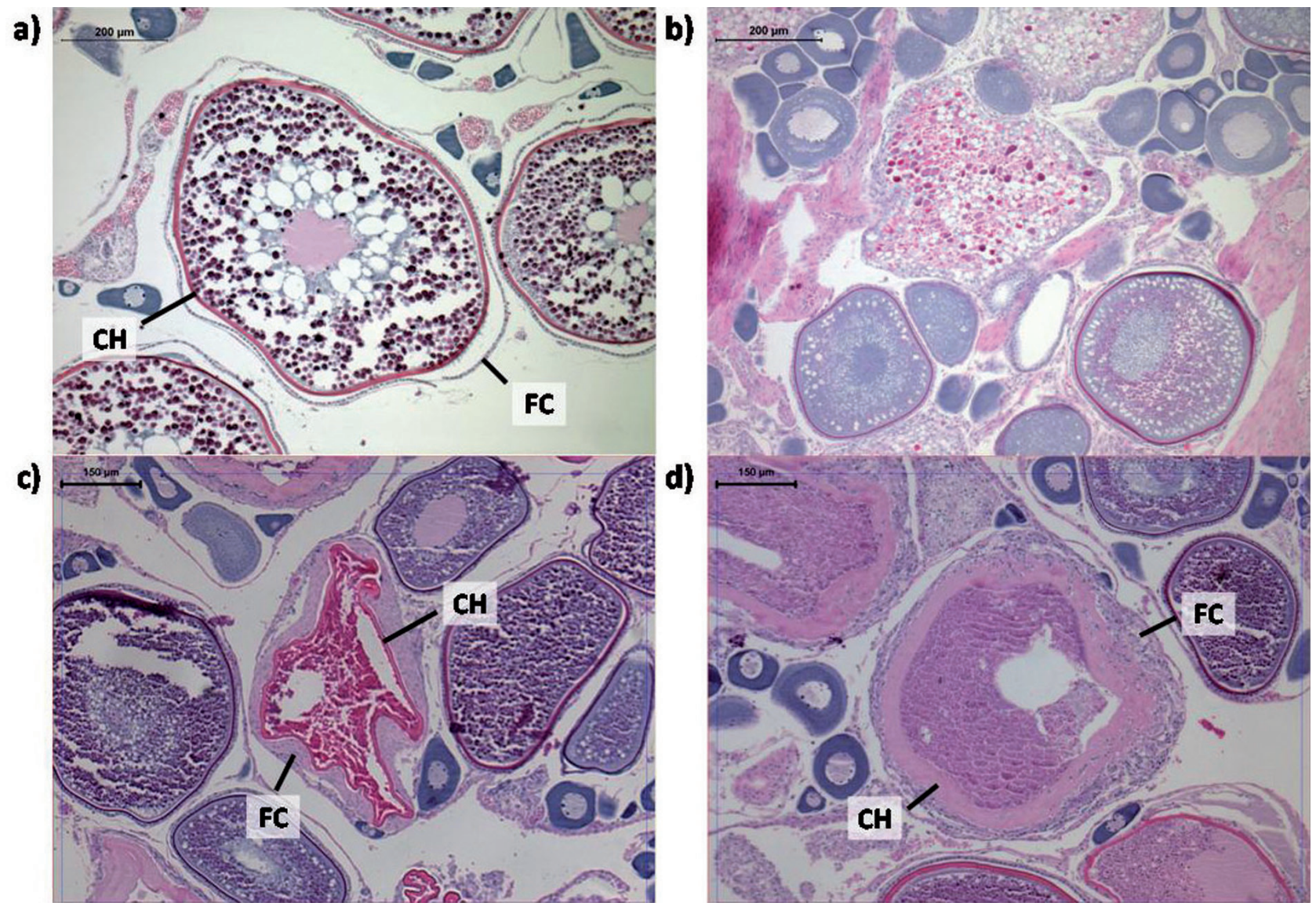

FIG. 1. - Histological images of European hake a) normal vitellogenic follicle (scale bar=200 um); b) normal atretic oocyte (Scale bar=200 $\mu \mathrm{m})$; c) cystic follicles with proliferation of follicular cell layers (scale bar=150 $\mu \mathrm{m}$ ) and d) cystic follicle with proliferation of follicular cell layers and a swollen chorion. FC, Follicular cells; $\mathrm{CH}$, chrorion. Scale bar=150 $\mu \mathrm{m}$.

For the European hake data for all years were pooled together by month. For the study period 143 females with cysts were analyzed. For each month the number of analysed females with cysts ranged between 10 and 18, except in September, November and December when only 7, 6 and 3 specimens, respectively were studied. In this species the relationship of cyst prevalence with length and condition factor was studied based on generalized linear models (GLM) and nonlinear models (GLZ), respectively, weighted by the number of samples in both cases. The total number of Atlantic cod samples analysed was 259 distributed by year (from 15 samples in 2003 to 96 samples in 2006). For this species the relationship between cyst prevalence and length was studied via GLM, while GLZ was used to examine the relationship of cyst prevalence to age and condition factor. Effects of age on cyst prevalence and intensity were not studied in hake due to the inaccuracy of present hake age reading methods (Piñeiro and Saínza, 2003).

The variation of cyst intensity between age and sampling months and years was analysed using a Kruskall-Wallis non-parametric test, due to the nonnormal distribution of data and the lack of homogeneity of variance, which prevented any appropriate data transformation. The relationship of cyst intensity to length and to condition factor was studied by GLM in both species. For the annual statistical analysis of cyst intensity in hake, only females from the first half of the year were included as no samples were collected from July to December of 1999 and 2000. All results are presented as mean \pm standard error.

\section{RESULTS}

Of the total of female cod $(n=1097)$ and hake $(\mathrm{n}=2244)$ examined, cysts were observed in $299 \mathrm{cod}$ measuring between 29 and $116 \mathrm{~cm}$ and in 555 hake measuring between 43 and $78.5 \mathrm{~cm}$.

\section{Cyst structure}

Cysts are abnormal structures in which follicular cuboidal epithelial cells proliferate and form a nonkeratinized multilayer epithelium. A normal follicle is composed of an oocyte surrounded by two cellular layers: the granulosa and the theca (Fig. 1a). The normal atretic process (Fig. 1b) begins with the proliferation of follicular cells which fragment the vitelline envelope, invading the ooplasm and digesting it via phagocytosis 


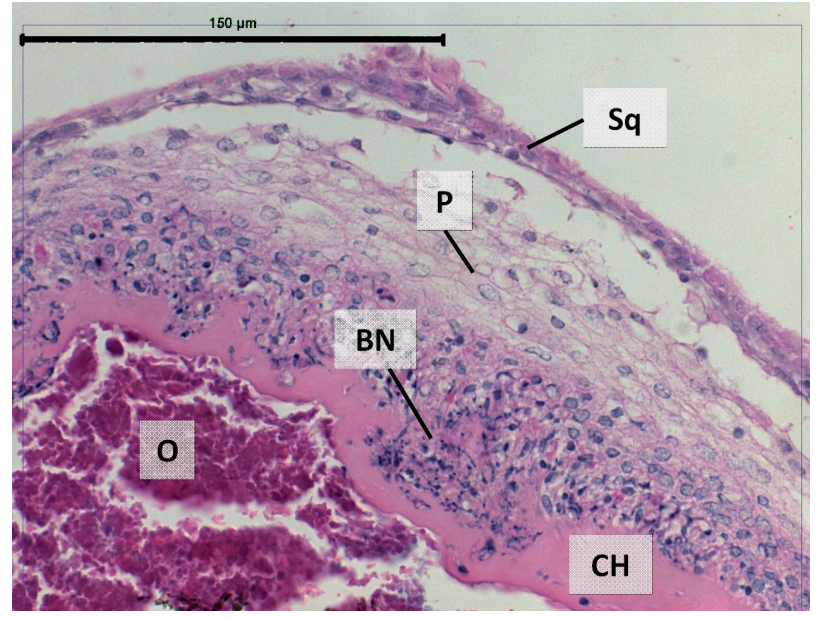

FIG. 2. - Stratified squamous epithelium structure of a cyst. Sq, squamous cells; $\mathrm{P}$, epithelial cells with vesiculous nucleus; $\mathrm{CH}$, chorion; $\mathrm{BN}$, necrotic cells with hyperchromatic nucleus; O, ooplasm. Scale bar $=150 \mu \mathrm{m}$

until total oocyte disintegration occurs, along with the collapse of the follicular envelope. However, in some cases the chorion does not break and the follicle envelope develops into a cyst (Fig. 1c, d). The cyst envelope comprises several cells layers. In general, the cells from the stratified epithelium show more cytoplasm and their nuclei are paler than in typical follicular cells. This type of nucleus is called a vesiculous nucleus and its pale colour may be due to decreased chromatin or to cytoplasmic inclusions. Cyst envelope is performed by a different number of cell layers and some differences are observed in cells shape from the inner to the outer layer of the cyst. In the basal area small cells with an irregular hyperchromatic nucleus and little cytoplasm are observed. In the intermediate layers, cells are large and have vesiculous nuclei (as described above) and they become squamous cells in the superficial layer (Fig. 2). Cells with irregular hyperchromatic nucleus are probably necrotic epithelial cells. Rarely, multinuclear cells and macrophages and circular structures formed by concentric layers of squamous cells are detected within the cyst envelope (Fig. 3a). Vacuoles are commonly seen (Fig. 3b). A thickening of the chorion usually occurs, and may occupy the entire oocyte lumen (Fig. 1d); this may be a sign of advanced cyst degeneration, though it is not seen in all follicles (Fig. 1c). Cystic structures occur across all stages of ovarian development (from pre-spawning to inactive ovaries) and seem to be randomly distributed in the gonad section (from the lumen to the ovary wall).

\section{Prevalence}

In European hake, cyst prevalence increased significantly from $17 \%$ in 1999 to more than $30 \%$ in 2002 , then decreased to $20 \%$ in 2004 (GLZ, N=2684, $P<0.01$. Fig. 4a). Cyst prevalence showed two peaks during the year, with the primary peak in September (37\%) and the secondary one in April (26\%). Minimum values were recorded in February (11\%) and December (12\%; Fig. 4b). Cyst prevalence increased significantly with female length following a linear relationship (GLM, $\mathrm{n}=2684, r^{2}=0.74, P<0.01$; Fig. $\left.4 \mathrm{c}\right)$ and decreased exponentially as condition factor increased (GLZ, $n=2684$, $r=-0.88, P<0.01$; Fig. $4 d)$.

Atlantic cod samples were caught exclusively in summer, and mainly between June and July. In general the mean summer values of cyst prevalence were similar for Atlantic cod and European hake between 2002 and 2004 (20-30\%). In Atlantic cod, cyst prevalence has increased significantly in recent years (GLZ, $\mathrm{n}=1332, P<0.01$; Fig. 5a) from $13 \%$ in 2001 to $31 \%$ in 2004 , decreasing slightly to $29 \%$ in 2006 . Cod cyst prevalence also increased significantly with age (GLM, $\mathrm{n}=1332, r^{2}=0.78, P<0.01$; Fig. $\left.5 b\right)$; in 1 and 2 year old females cyst prevalence was lower than $2 \%$, whereas in older specimens $(9+)$ it reached more than $60 \%$. The only two 11-year-old females sampled both had cysts. Cyst prevalence was significantly related to length in this species as well, but fitted to a logistic curve (Logit, $\mathrm{n}=1332, r^{2}=0.62, P<0.01$; Fig. 5c). A significant relationship was also found between cyst prevalence and condition factor in the Atlantic cod, but the inverse a)

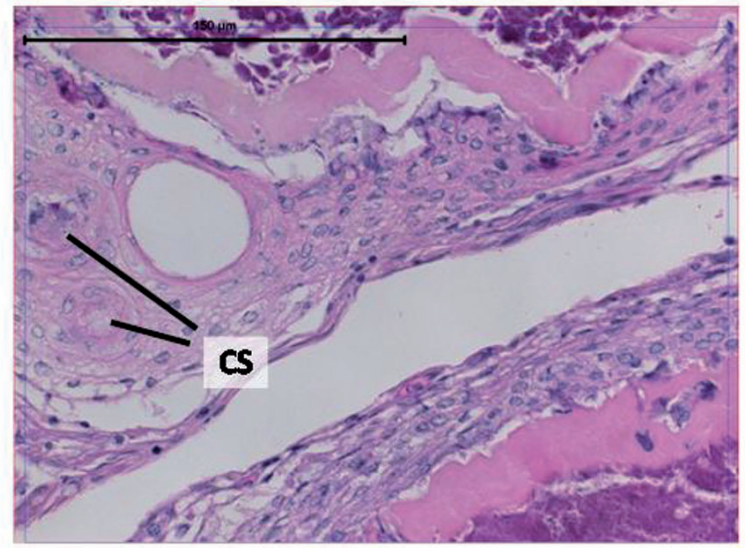

b)



FIG. 3. - Microphotography of a) circular structures (CS) formed of concentric layers of squamous cells and b) vacuoles (V). Scale bar=150 $\mu \mathrm{m}$ 
a)

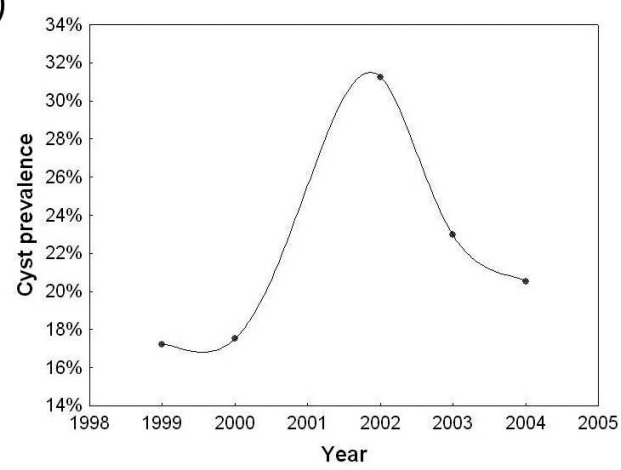

c)

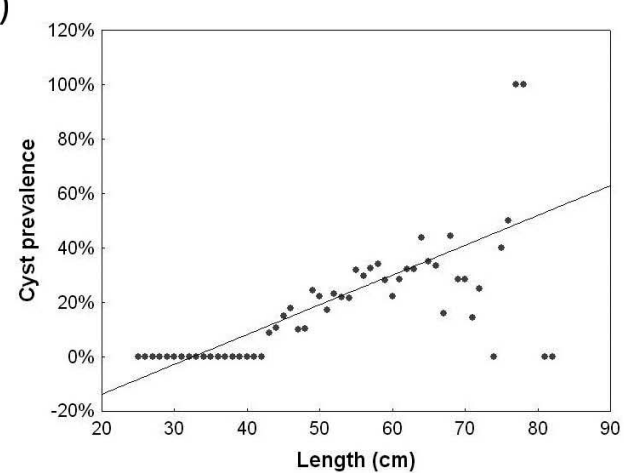

b)

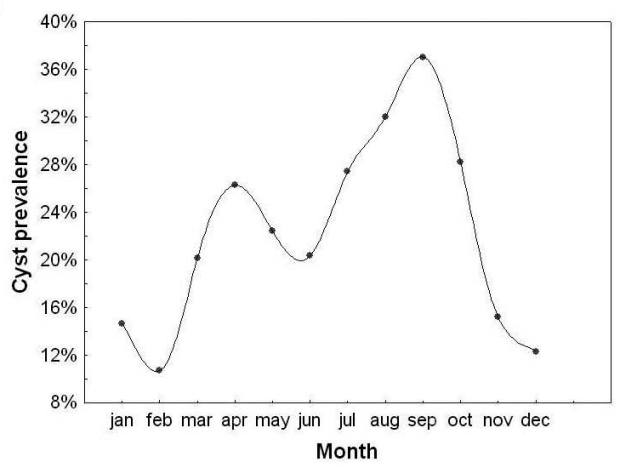

d)

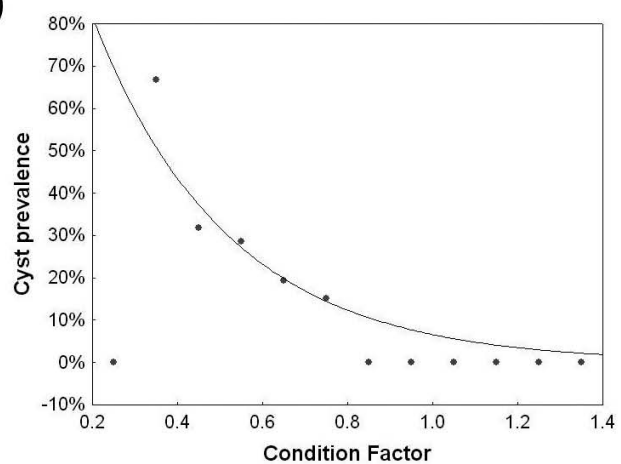

FIG. 4. - For European hake: a) annual mean of cyst prevalence; b) monthly mean of cyst prevalence; c) linear relationship between cyst prevalence and female length $(\mathrm{y}=-0.3557+0.0109 \mathrm{x})$; and $\mathrm{d})$ exponential relationship between cyst prevalence and female condition factor $\left(\mathrm{y}=1.2251 \cdot \mathrm{e}^{-2.7949 x}\right)$

a)

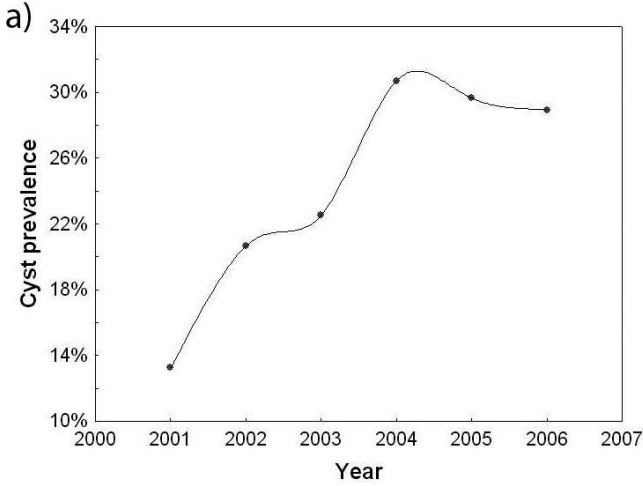

c)

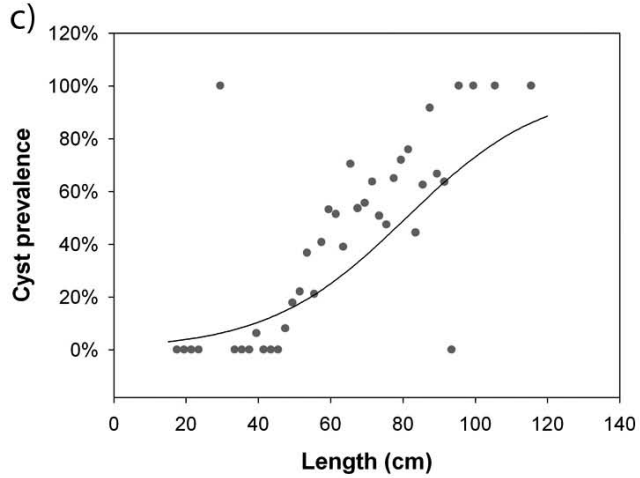

b)

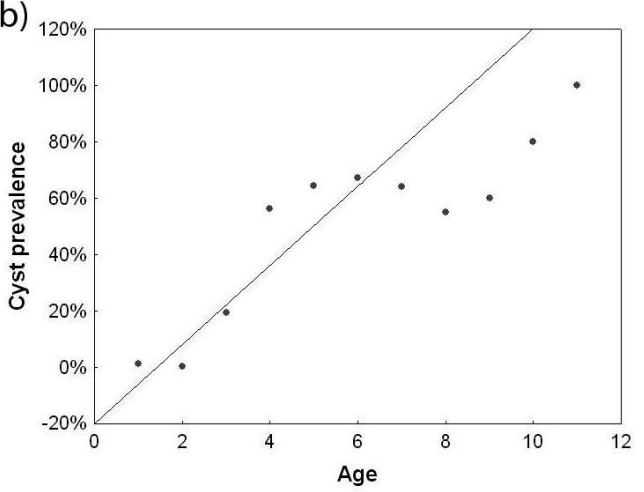

d)

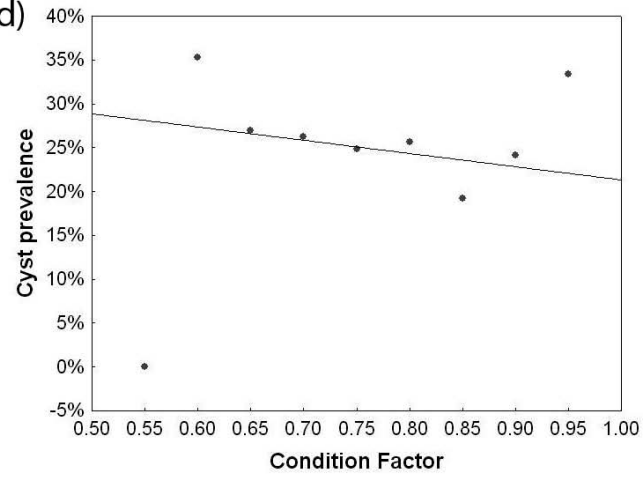

FIG. 5. - For Atlantic cod: a) annual mean of cyst prevalence; b) mean of cyst prevalence by female age (y=0-0.1998+0.1403x); c) logistic relationship between cyst prevalence and female length $\left(y=e^{(-4.247+0.052 x)} / 1+e^{(-4.247+0.052 x)}\right)$; and $\left.\mathrm{d}\right)$ linear relationship between cyst prevalence and female condition factor $(\mathrm{y}=0.3641-0.1509 \mathrm{x})$. 
a)
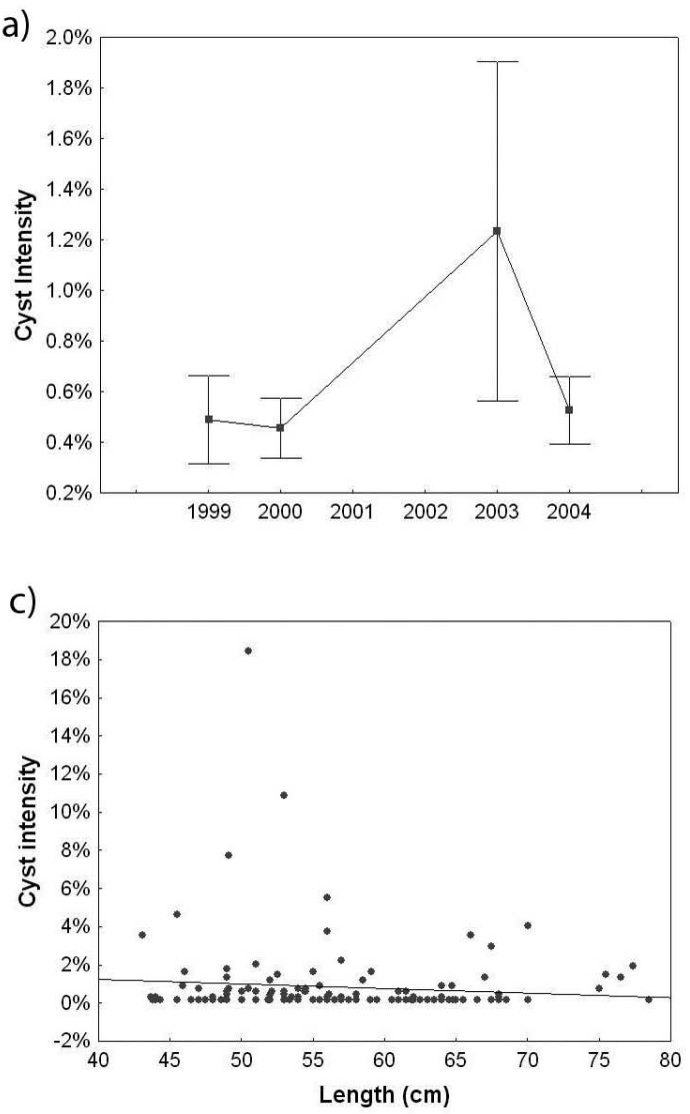

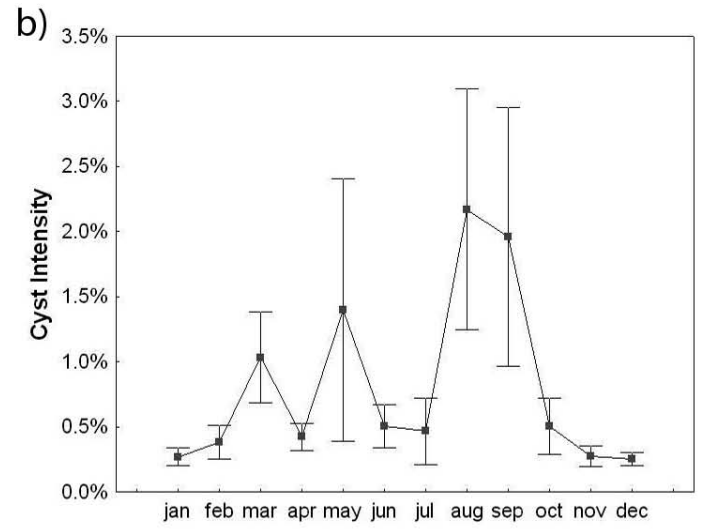

d)

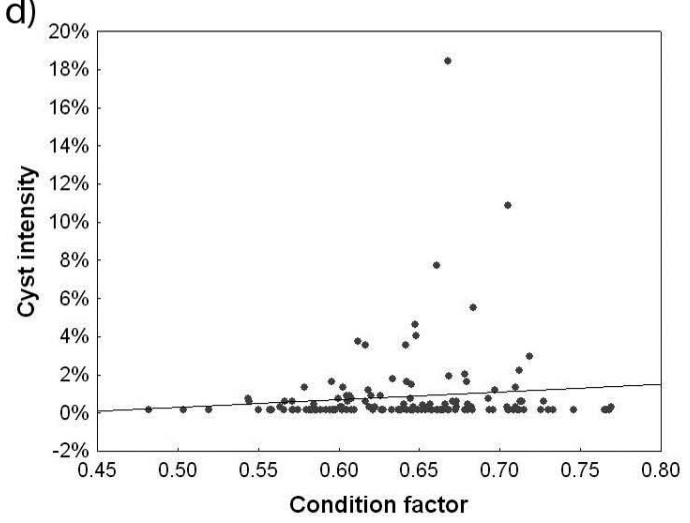

FIG. 6. - For European hake: a) annual mean \pm standard error of cyst intensity; b) monthly mean \pm standard error of cyst intensity; c) linear relationship between cyst intensity and female length $(\mathrm{y}=0.022-0.0002 \mathrm{x})$; and $\mathrm{d})$ linear relationship between cyst intensity and female condition factor $(\mathrm{y}=-0.0171+0.0402 \mathrm{x})$.

relationship was linear rather than exponential as in hake (GLM, n=1332, $r^{2}=0.11, P<0.01$; Fig. 5d). No European hake with a condition factor higher than 0.8 showed cysts, while Atlantic cod with the same condition had a cyst prevalence of more than $15 \%$.

In European hake cyst prevalence was related to the maturity stage (pre-spawning, spawning and inactive). Only $19.93 \%$ of pre-spawning females showed cysts compared with $26.55 \%$ and $33.05 \%$ of spawning and inactive females, respectively. In the case of Atlantic cod, all samples came from summer, which means that all of them were inactive ovaries, but information on whether females were primiparous was available. Only one primiparous female cod showed cysts $(1.52 \%)$, while $57.09 \%$ of multiparous females had cysts.

\section{Intensity}

Cyst intensity in European hake females was relatively low (0.15-18.5\%). Most females showed cyst intensity lower than $5 \%$, though some specimens with higher intensity appeared in all years except 2000. Maximum intensity (18.5\%) was observed in a specimen from May 2003. Cyst intensity did not vary significantly between years (K-W ANOVA, $\mathrm{n}=88, P>0.05$, Fig. 6 a) or months (K-W ANOVA, N=143 P>0.05, Fig. 6b). However, though it was not significant, an increase in cyst intensity was observed one month after the main spawning peak in February and during the secondary spawning peak (May-August, depending on the year). No significant relationship was observed between cyst intensity and length $\left(r^{2}=0.01, P>0.05 ;\right.$ Fig. $\left.6 \mathrm{c}\right)$ or condition factor $\mathrm{K}\left(r^{2}=0.01\right.$, $P>0.05$; Fig. $6 \mathrm{~d}$ ), though the highest values of cyst intensity corresponded to females smaller than $60 \mathrm{~cm}$ with a condition factor higher than 0.65 .

For Atlantic cod, cyst intensity varied between $0.1 \%$ and $23 \%$. The Kruskall-Wallis test did not show significant differences between years (K-W ANOVA, $\mathrm{n}=259, P>0.05$, Fig. 7 a). Maximum intensity occurred in 2004 and 2005, though high values were also detected in 2002. No significant relationship was found between cyst intensity and age (K-W ANOVA, $n=257$, $P>0.05$, Fig. $7 b$ ), though there was a general trend towards lower intensity in older females, from $3.4 \pm 1.1 \%$ in 3 year old females to $0.2 \%$ in 10 year old females, increasing slightly to $1.6 \pm 0.1 \%$ in 11 year old females. Cyst intensity decreased significantly with length in the Atlantic cod (GLM, $\mathrm{n}=259, r^{2}=0.02, P<0.05$; Fig. $7 \mathrm{c}$ ), although the correlation coefficient was low, but as in the European hake no significant relationship was found between cyst intensity and condition factor (GLM, n=259, $r^{2}=0.01, P>0.05$; Fig. 7d). For the 
a)

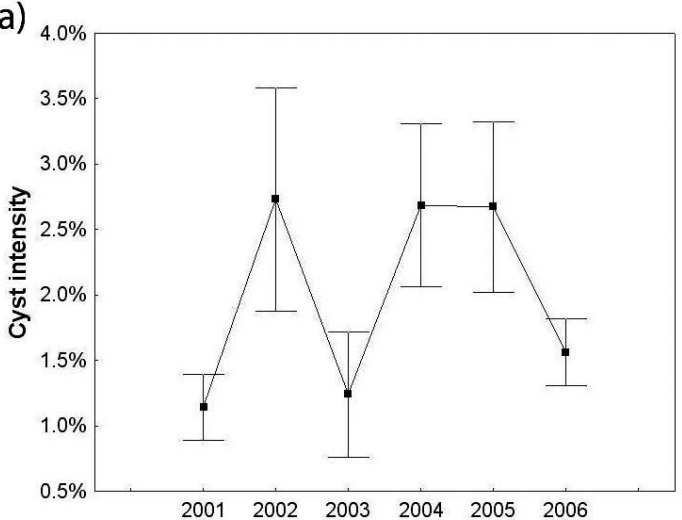

c)

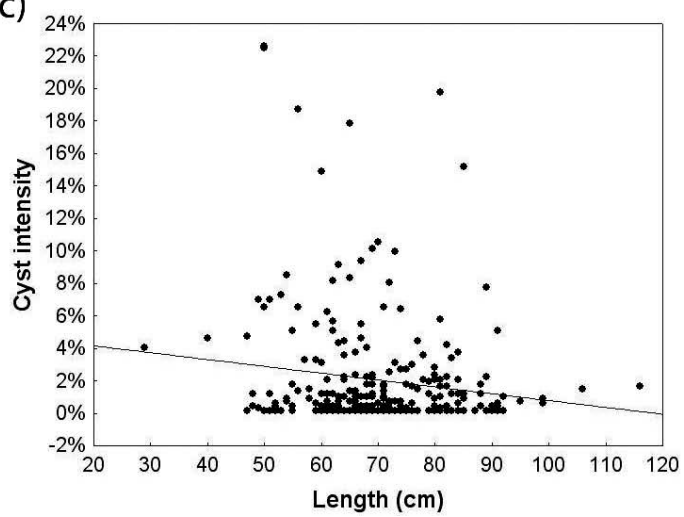

b)

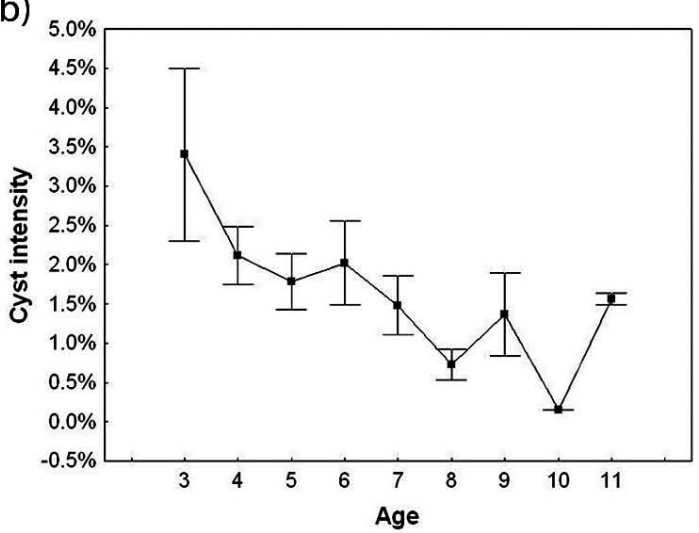

d)

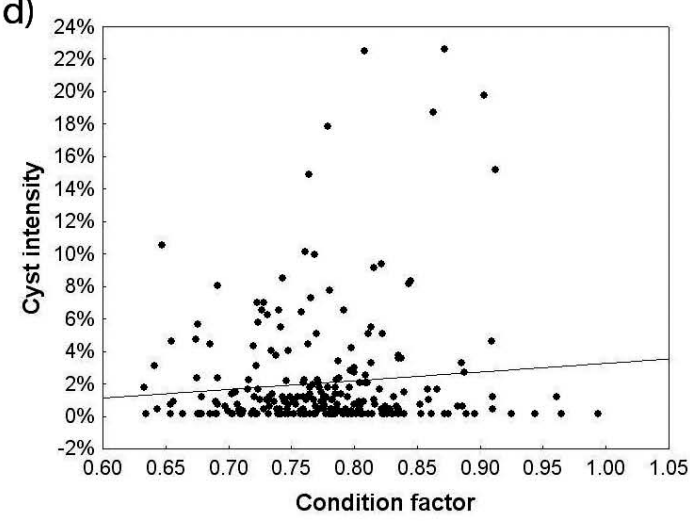

FIG. 7. - For Atlantic cod: a) annual mean \pm standard error of cyst intensity; b) mean \pm standard error of cyst intensity by age; c) linear relationship between cyst intensity and female length $(\mathrm{y}=0.05-0.0004 \mathrm{x})$; and $\mathrm{d})$ linear relationship between cyst intensity and female condition factor $(y=-0.021+0.0534 x)$.

Atlantic cod, the highest values of cyst intensity were observed in females between 50 and $90 \mathrm{~cm}$ in fairly good condition $(>0.75)$.

Regarding relationship between cyst intensity and maturity stage, in European hake pre-spawning females showed a mean intensity of $0.57 \%$ and a maximum intensity of $10.86 \%$. Spawning females showed a mean intensity of $0.44 \%$ and a maximum intensity of $4.61 \%$, whereas inactive females showed a mean intensity of $2.32 \%$ and a maximum intensity of $18.45 \%$. In Atlantic cod primiparous females showed mean intensity of $0.15 \%$, while multiparous females had a mean intensity of $2.04 \%$ and a maximum intensity of $22.62 \%$.

\section{DISCUSSION}

In normal mature follicles of Atlantic cod and $\mathrm{Eu}$ ropean hake the superficial epithelium is simple and cuboidal, in contrast with the multilayered cyst envelope, which has progressively larger cells in each layer. This organization is typical of squamous stratified epithelium. However, while the typical squamous stratified epithelium shows a basal layer formed of cuboidal cells (Young and Heath, 2002), basal layer cells from oocyte cysts are not cuboidal and some of them are often necrotic.
In general, a simple cuboidal epithelium is associated with ducts and tubules with secretory, excretory or absorption functions, whereas a stratified squamous epithelium is typically related to protective functions due to its abrasion resistance (Young and Heath, 2002). Fish oocyte epithelium has several functions depending on the species, including the transport of different chemical compounds into the oocyte, vitellogenesis, the production of the secondary envelope around the zona pellucida, steroidogenesis and mechanical functions facilitating ovulation (McMillan, 2007). The functionality of the oocyte epithelium probably changes when it becomes squamous and multistratified. The presence of some macrophages and multinuclear cells within the cyst envelope may indicate an inflammatory response, although macrophages are usually observed in normal atretic follicles too (Besseau and Faliex, 1994; Nourani et al., 2005).

The number of cells layers in the epithelium could be related to the cyst degeneration process. Cyst formation could start with a proliferation of cells with a vesiculous nucleus that are organized in different layers (few at the beginning). When degeneration advances, oocyte resorption continues and the number of epithelial layers increases. The presence of necrotic cells in the cyst basal layers may indicate an advanced 
degeneration stage. Hypothetically, at the end of cyst degeneration the oocyte would be completely resorbed and epithelial cells would take up the whole space previously occupied by the oocyte. The time necessary to complete cyst degeneration process is unknown, but is probably related to environmental temperature, as is discussed below. The number of cell layers and the presence of necrotic cells can be used as markers to date cysts.Circular structures similar to those observed in oocyte cysts (Fig. 3a) have only been reported in human beings and always associated with squamous epithelial carcinomas. In these cases, the structures can be keratinized and are called squamous, epithelial or keratin pearls (Iacocca et al., 1998; Schultz and Mantsch, 1998; Pool et al., 1999; Junichi et al., 2005). In the current literature there are no references to keratin pearls in fish or any accounts of keratin pearl resorption in humans. If the circular structures observed in the present work correspond to keratin pearls, they could remain in the fish ovary for long periods of time, even after the oocyte has been completely resorbed, reducing egg production capacity. The vacuoles could be glycogen accumulations or the consequence of degenerative changes due to macrophages activity (Dr. Yale Rosen, pers. comm.). New staining methods specific to keratin and glycogen are currently being applied to fish ovaries with cysts to determine whether the observed circular structures correspond to keratin pearls and to clarify the origin of the vacuoles.

Few references concerning fish oocyte cyst (Louge, 1996; Tomkiewicz et al., 2003, Witthames et al., 2010) are available for comparison with these results. Hydrated oocytes of some species from the genus Perca have a thickened viteline envelope similar to those observed in oocyte cysts (Sulistyo et al., 1998; Blazer, 2002), but this swelling is part of the normal oocyte development of these species and is not associated with any abnormal processes. Current data do not allow us to confirm that cyst formation is exclusively due to a pathological process, although it is likely related to an inflammatory response. One hypothesis would be that when the follicle begins to degenerate due to atresia it may be recognized as a foreign or damaged cell, causing an immune reaction that leads to an inflammatory process and stratification of superficial epithelium. This hypothesis is supported by the presence of inflammatory cells as macrophages. The inflammatory response is an innate immune mechanism that occurs in connective vascularized tissues with the aim of isolating and destroying pathogens or repairing damaged tissues (Abbas and Lichtman, 2004). Cysts would never be released, so in practice the impact of cysts on fecundity would be comparable to the effects of atresia. In addition, cysts or their associated structures may remain in the ovary for long periods of time, affecting future reproductive potential. Cyst resorption time is unknown, but it seems likely that this process occurs more slowly than normal atresia because cysts remain in the ovary even when there are no signs of previous spawning activity. Nevertheless, it could be modulated by the same factors: female physiological condition (Kjesbu et al., 1991; Rideout et al., 2000; Óskarsson et al., 2002; Hardardóttir et al., 2003), female size and age (Engelhard and Heino, 2006; Rideout and Rose, 2006), stressing factors like temperature changes (Fedorov, 1971; Linares-Casenave et al., 2002), food availability (Gerking, 1967; Solemdal, 1997), parasitism or disease (Roberts, 2001; Clarke et al., 2006), intra-specific competition (Privalikhin, 2003), and anthropogenic effects (Wootton, 1990; Oven, 2004). In the present work we observe that in general, in both hake and cod, cyst intensity is not significantly related to length, age or condition. However, the highest values of cyst intensity were observed in smaller hake and younger cod: young, less-experienced females seem to show more cysts than older ones. This pattern has also been observed in classical studies of atresia in cod from other areas (Rideout et al., 2000) and in other species (Rideout and Rose, 2006) where the intensity of atresia is higher in young females. In contrast, physiological condition usually influences atresia intensity (Solemdal, 1997; Rideout et al., 2000; Hardardóttir et al., 2003), but did not show a significant impact on cyst intensity for cod or hake. Moreover, in both species the highest values of cyst intensity are observed in females with a relatively good condition factor. Thus, cyst intensity may be more affected by environmental factors such as temperature, food availability and stressors than by the female's somatic and physiological attributes. In this study the effect of environmental factors was not analysed, but they could affect the rate of cyst incidence either directly, if stressors increase cyst formation, or indirectly, by controlling cyst resorption rate and consequently their accumulation in the ovary. Oocyte resorption by atresia is known to be stimulated by changes in environmental temperature (Koger et al., 1999; Rideout et al., 2000; Linares-Casenave et al., 2002), and the residence time of other ovary structures, like post-ovulatory follicles, is also regulated by temperature (Fitzhugh and Hettler 1995, and references therein), so it is reasonable to conjecture that temperature also influences cyst occurrence and resorption. Low temperatures could slow down cyst resorption and increase accumulation in the ovary, which would explain the higher prevalence and intensity of cyst in Atlantic cod from the cold waters of the Flemish Cap than in European hake from the temperate waters of the Galician shelf. These two gadiforms are very different, though they play a similar role within the demersal ecosystem, so the effect of temperature on cyst resorption cannot be demonstrated. More experiments must be carried out to determine the impact of water temperature on cyst resorption rates.

In general, the number of females with cysts has increased for cod over the past few years, perhaps induced by changes in habitat characteristics or stock structure. In the case of hake, although cyst prevalence in 2003 and 2004 was higher than in 1999 and 2000, 
maximum values were recorded in 2002. Cyst prevalence increases significantly with length in both species and also with age in cod; therefore, females with cysts are more common in stocks with larger individuals and/or those of lower condition, but these females have lower cyst intensity. In hake, cyst prevalence increases linearly with length, while in cod the relationship is logistic. Furthermore, in the case of Atlantic cod, 57.09\% of multiparous females had cysts in comparison with only $1.52 \%$ of primiparous individuals. This pattern may indicate that there is a cumulative effect of length on cyst prevalence. The length of sampled hake females (25-82) is lower than the length of sampled cod females $(17-116 \mathrm{~cm})$; analysing the length-prevalence plot carefully, we observed that both species show the same pattern up to $80 \mathrm{~cm}$, after which no data are currently available for hake. It is likely that length would also have a cumulative effect in this species, yielding a logistic relationship with cyst prevalence, if large females were sampled.

Cyst prevalence is negatively related to female condition in both species, exponentially in hake and linearly in cod, i.e. high-condition females have a lower probability of having cysts than low-condition ones. Two possible causes of this effect are that females in good condition i) do not develop as many cysts or ii) resorb them more quickly. A similar pattern may apply to age; the cyst intensity/prevalence-age relationship in cod yields a trend of higher cyst prevalence and lower cyst intensity in older females. In relation to the maturity stage, differences in cyst intensity between prespawning, spawning and inactive hake females were small, although the maximum values were recorded for inactive females. In the case of cod, in both primiparous and multiparous females cyst intensity was low, although the highest value $(22.62 \%)$ was reached by multiparous fish. These results must be interpreted with caution because only one primiparous female showed cysts. However, the high cyst prevalence of multiparous females suggests that the more spawning events females experiment, the more likely this phenomenon is.

In European hake monthly data of cyst intensity and prevalence seem to be associated with the declines in spawning activity, as happens with atresia. This correlation further suggests a connection between cyst formation and oocyte resorption, indicating that the former is likely to be affected by many of the same factors that regulate normal atresia. The reason why cyst formation occurs in place of normal atresia remains unknown, but the impact of cyst formation on a stock's reproductive potential is beyond question. The cysts take up space that should be used for healthy developing oocytes; if keratin pearls are also present, they would further limit reproduction. In some females more than $15 \%$ of total mature oocytes are cysts; if they persist in the ovary for long periods of time as the prevalence results suggest, their impact on stock reproduction could be very great. As the cyst phenomenon is largely unstudied, further research into the factors that cause cyst formation is necessary and must include the impacts of environmental stressors such as temperature changes, prey shortages, interspecific competition and pathological causes. The structure, composition and duration of cysts in the ovary also merits further investigation using immunohistochemical methods to classify accurately different cells and structures observed in the cyst. The study of mechanisms of cyst formation and the real impact that these structures have on SRP is required to estimate the impact of cyst intensity on fish reproduction and, subsequently, in stock assessment.

\section{ACKNOWLEDGEMENTS}

This work was supported by the Reproduction and Stock Evaluation for Recovery Project (Q5RS2002-01825), which forms part of the $5^{\text {th }}$ Framework Programme "Quality of Life and Management of Living Resources" and the Galicia Government Project XUGA-40201B98. This article was encouraged by discussions with and the terms of reference of the NAFO Working Group on Reproductive Potential and COST Action "Fish Reproduction and Fisheries" (FRESH, FA0601). We would like to thank Rosa Collazo, Dolores Dominguez, Mariña Fabeiro and Sonia Rábade for their technical support. We are also very grateful to $\mathrm{R}$. Rideout for his constructive comments and essential corrections and to Dr. Y. Rosen and Dr. C. Fiaño-Valverde for their invaluable help with histology. Finally, we thank Dr. R. Osborne and Dr. P. Grimes for sharing their personal findings of cysts in other species.

\section{REFERENCES}

Abbas, A.B. and A.H. Lichtman. - 2004. Basic Immunology. Functions and disorders of the immune system (3rd edn.). Saunders (Elsevier)

Besseau, L. and E. Faliex. - 1994. Resorption of unemitted gametes in Lithognathus mormyrus (Sparidae, Teleostei): a possible synergic action of somatic and immune cells. Cell. Tiss. Res., 276: 123-132

Blazer, V.S. - 2002. Histopathological assessment of gonadal tissue in wild fishes. Fish Physiol. Biochem., 26: 85-101.

Bromley, P.J., C. Ravier and P.R. Witthames. - 2000. The influence of feeding regime on sexual maturation, fecundity and atresia in first-time spawning turbot. J. Fish Biol., 56(2): 264-278.

Clarke, L.M., A.D.M. Dove and D.O. Conover. - 2006. Prevalence, intensity and effect of a nematode (Philometra saltatrix). Fish. Bull., 104: 118-124.

Dominguez-Petit, R. and F. Saborido-Rey. - 2005. New atretic structures identified in ovary of European hake (Merluccius merluccius, L. 1758) in Galician coast. ICES Annual Science Conference. September 20-24 2005 (Aberdeen, UK). CM 2005/Q:36.

Dominguez-Petit, R. - 2007. Study of reproductive potential of Merluccius merluccius in the Galician Shelf. Doctoral Thesis. University of Vigo (Spain).

Engelhard, G.H and M. Heino. - 2006. Climate change and condition of herring (Clupea harengus) explain long-term trends in extent of skipped reproduction. Oecol., 146: 593-603.

Fedorov, K.Y. - 1971. The State of the gonads of the Brents Sea Greenland Halibut (Reinhardtius hippoglossoides, Walb.) in connection with failure to spawn. J. Ichthyol., 11(5): 673-681.

Fitzhugh, R.G. and F.W. Hettler. - 1995. Temperature influence on postovulatory follicle degeneration in Atlantic menhaden, 
Brevoortia tyrannus. Fish. Bull.93: 568-572.

Ganias, K., S. Somarakis, C. Koutsikopoulos, A. Machias and A. Theodorou. - 2003. Ovarian atresia in the Mediterranean sardine, Sardina pilchardus sardina. J. Mar. Biol. Ass. UK, 83(6): 1327-1332.

Gerking, S.D. - 1967. The Biological Basis of Freshwater Fish Production. Blackwell Scientific Publications.

Gundersen, H.J.G. and E.B. Jensen. - 1987. The efficiency of systematic sampling in stereology and its prediction. J. Microscp., 147: 229-263.

Guraya, S.S. - 1986. The cell and molecular biology of fish oogenesis In: H.W. Sauer (ed.), Monographics Developmental Biology, 18: 223.

Hardardóttir, K., O.S. Kjesbu and G. Marteinsdottir. - 2003. Atresia in Icelandic cod (Gadus morhua) prior to and during spawning. In: O.S. Kjesbu, J.R. Hunter and P.R. Witthames. Report of the Working Group on Modern Approaches to Assess Maturity and Fecundity of Warm- and Cold-water Fish and Squids. Fisk. Hav, 12: 99-104.

Hirshfield, A.N. - 1991. Development of follicles in the mammalian ovary. Inter. Rev. Citol., 124: 43-102.

Iacocca, M.V., J.L. Abernethy, C.M. Stefanato, A.E. Allan and J. Bhawan. - 1998. Mixed Merkel cell carcinoma and squamous cell carcinoma of the skin. J. Am. Ac. Dermatol., 39(2): 882-887.

Junichi, S., M. Makio, Y. Hiroo, S. Rie, Y. Taketo, M. Keiko, A. Ukei, M. Hideo and S. Michiie. - 2005. Primary bone carcinosarcoma: chondrosarcoma and squamous cell carcinoma with keratin pearl formation. Pathol. Int., 55(8): 504-509.

Kjesbu, O.S., J. Klungsoyr, H. Kryvi, P.R. Witthames and M. Greer Walker. - 1991. Fecundity, atresia and egg size of captive Atlantic cod (Gadus morhua) in relation to proximate body composition. Can. J. Fish. Aquat. Sci., 48: 2333-2343.

Koger, C.S., S.J. Teh and D.E. Hinton. - 1999. Variations of light and temperature regimes and resulting effects on Reproductive Parameters in Medaka (Oryzias latipes). Biol. Reprod., 61: $1287-1293$

Lilly, G. and A. Vázquez. - 2005. Flemish Cap (NAFO Division 3M). In: K. Brader (ed.), Spawning and life history information for North Atlantic cod stocks. ICES Coop. Res. Rep., 274: 90-94.

Linares-Casenave, J., J.P. Van Eenennaam and S.I. Doroshov. 2002. Ultrastructural and histological observations on temperature-induced follicular ovarian atresia in the white sturgeon. $J$. Appl. Ichthyol., 18: 382-390.

Louge, E.B. - 1996. Variaciones espacio-temporales del fenómeno reproductivo de la merluza Merluccius hubbsi (Marini, 1933) durante su concentración invernal en la zona común de pesca argentino-uruguaya. Bol. Inst. Esp. Oceanogr., 11: 123-139.

Marshall, C.T., L. O’Brien, J. Tomkiewicz, F.W. Köster, G. Kraus, G. Marteinsdottir, M.J. Morgan, F. Saborido-Rey, J.L. Blanchard, D.H. Secor, P.J. Wright, N.V. Mukhina and H. Björnsson. - 2003. Developing alternative indices of reproductive potential for use in fisheries management: case studies for stocks spanning an information gradient. J. Northwest Atl. Fish. Sci., 33: 161-190.

McMillan, D.B. - 2007. Fish Histology: Female Reproductive Systems. Springer.

Murua, H. and F. Saborido-Rey. - 2003. Female reproductive strategies of marine fish species of the North Atlantic. J. Northwest Atl. Fish. Sci., 33: 23-31

Murua, H. and L. Motos. - 2006. Reproductive strategy and spawning activity of European hake Merluccius merluccius (L.) in the Bay of Biscay. J. Fish Biol. 69: 1288-1303.

Murua, H., G. Kraus, F. Saborido-Rey, P.R. Witthames, A. Thorsen and S. Junquera. - 2003. Procedures to Estimate Fecundity of
Marine Fish Species in Relation to their Reproductive Strategy. J. Northwest Atl. Fish. Sci., 33: 33-54.

Nourani, M.R., Y. Owada, N. Kitanaka, S.A. Abdelwahab, H. Iwasa, H. Sakagami, F. Spener and H. Kondo. - 2005. Localization of epidermal-type fatty acid binding protein in macrophages in advanced atretic follicles of adult mice. J. Mol. Histol., 36: 391-400.

Óskarsson, G.J., O.S. Kjesbu and A. Slotte. - 2002. Predictions of realised fecundity and spawning time in Norwegian springspawning herring (Clupea harengus). J. Sea Res., 48: 59-79.

Oven, L.S. - 2004. Resorption of vitellogenous oocytes as an indicator of the state of the Black Sea fish populations and their environment. J. Ichthyol., 44(1): 115-119.

Piñeiro, C. and M. Saínza. - 2003. Age estimation, growth and maturity of the European hake (Merluccius merluccius) from Iberian Atlantic waters. ICES J. Mar. Sci., 60: 1086-1102.

Pool, S., F. Manieei, W. Clark and T. Harrist. - 1999. Dermal squamo-melanocytic tumor: A unique biphenotypic neoplasm of uncertain biological potential. Hum. Pathol., 30(5): 525-529

Privalikhin, A.M. - 2003. Resorption of developing oocytes as a regulatory mechanism of formation of individual and population fecundity in Walleye Pollock Theragra chalcogramma (Gadidae). J. Ichthyol., 43(6): 454-463.

Rideout, R.M. and G.A. Rose. - 2006. Suppression of reproduction in Atlantic cod Gadus morhua. Mar. Ecol. Prog. Ser., 320: 267-277.

Rideout, R.M., M.J. Morgan and G.R. Lilly. - 2006. Variation in the frequency of skipped spawning in Atlantic cod (Gadus morhua) off Newfoundland and Labrador. ICES J. Mar. Sci., 63: 1101-1110.

Rideout, R.M., M.P. Burton and G.A. Rose. - 2000. Observations on mass atresia and skipped spawning in northern Atlantic cod, from Smith Sound, Newfoundland. J. Fish. Biol., 57: 1429-1440.

Roberts, R.J. - 2001. Fish Pathology. $3^{\text {rd }}$ edn. W.B. Saunders. London.

Saidapur, S.K. - 1978. Follicular atresia in the ovary of nonmammalian vertebrates. In: G.H. Bourne, J.F. Danielli and K.W. Jeon (ed.). Intern. Rev. Cyt., 54: 225-244.

Schultz, C.P. and H.H. Mantsch. - 1998. Biochemical imaging and 2D classification of keratin pearl structures in oral squamous cell carcinoma. Cell. Mol. Biol., 44(1): 203-210.

Solemdal, P. - 1997. Maternal effects: a link between the past and the future. J. Sea Res., 37: 213-227.

Sulistyo, I., J. Rinchard, P. Fontaine, J.N. Gardeur, B. Capdeville and P. Ketesmont. - 1998. Reproductive cycle and plasma levels of sex steroids in female Eurasian perch Perca fluviatilis. Aquat. Liv. Resour., 11(2): 101-110.

Tomkiewicz, J., L. Tybjerg and A. Jespersen. - 2003. Micro and macroscopic characteristics to stage gonadal maturation of female Baltic cod. J. Fish Biol., 62: 253-275.

Weibel, E.R. - 1979. Stereological methods. Practical methods for Biological Morphometry, 1. Academic Press. Florida (USA).

Witthames, P.R, A. Thorsen and O.S. Kjesbu. - 2010. The fate of vitellogenic follicles in experimentally monitored Atlantic cod Gadus morhua (L.): Application to stock assessment. Fish. Res., 104: 27-37.

Wootton, R.J. - 1990. Ecology of Teleost Fishes. Fish and Fisheries Series, 1. Chapman and Hall.

Young, B. and J.W. Heath. - 2002. Histología Funcional de Weather. $4^{\text {th }}$ edn. Harcourt. Churchill Livingstone. Madrid.

Scient. ed.: S. Zanuy.

Received May 31, 2010. Accepted October 21, 2010

Published online March 14, 2011. 